\title{
Köpek, sığır, keçi ve koyunlarda mavi dil seroprevalansı
}

\author{
Elif Bayram ${ }^{1}$, Semra Okur Gümüşova ${ }^{1}$
}

${ }^{1}$ Viroloji Anabilim Dalı, Veteriner Fakültesi, Ondokuz Mayıs Üniversitesi, Samsun/TÜRKIYYE

Anahtar Kelimeler:
mavidil virus
seroprevalans
keçi
koyun
köpek
sığı1r

Key Words:
bluetongue virus
seroprevalance
goat
sheep
dog
cattle

Gelis Tarihi $\quad: 06.04 .2021$

Kabul Tarihi $\quad: 07.10 .2021$

Yayın Tarihi $\quad: 31.12 .2021$

Makale Kodu : 910665

Sorumlu Yazar:

SO, GÜMÜSOVA

(semragumusova@hotmail.com)

ORCID

E. BAYRAM : 0000-0003-3190-4486

SO. GÜMÜŞOVA: 0000-0003-3354-8489
ÖZ

'Türkiye' de köpeklerde mavi dil seroprevalansının ilk kez araştırıldığı bu çalışmada Ondokuz Mayıs Üniversitesi Veteriner Fakültesi Hayvan Hastanesi'nde 6 ilden (Ordu, Samsun, Giresun, Artvin, Trabzon ve Sinop) daha önce distemper ve/veya parvovirus aşılaması yapılmış köpekler örneklendi. Ayrıca Samsun, Sivas ve Tokat' dan mavi dil aşılaması yapılmamış sürülerden örneklenen sığır, keçi ve koyun kan numuneleri de mavi dil seroprevalansı yönünden incelendi. Çalışma için toplanan tüm serum örneklerinde mavi dil virus antikorlarının varlığı ticari c-ELISA kiti kullanılarak araștırıldı. ELISA testi sonunda köpek ve sığırların kan serumlarında mavi dil enfeksiyonuna karşı seropozitiflik saptanmazken, keçi ve koyun serumlarında ise seroprevalans, \%65.2 (Tokat ve Samsun) ve \% 8.6 (Sivas) olarak tespit edildi. Çalışma sonunda hem koyun hem de keçilerde seropozitifliğin belirlendiği iller ve çevresinde daha kapsamlı araştırmaların planlanması ve özellikle bu illerdeki sokak köpeklerinde ayrıntılı bir taramanın yapılması gerektiği sonucuna varıldı.

\section{Bluetongue seroprevalence in dog, cattle, goat and sheep}

\begin{abstract}
The Bluetongue seroprevalence in dogs were investigated in this study for the first time In Turkey, For this aim, blood samples of dog that were vaccinated with distemper and/or parvovirus vaccine were collected in the 19 Mayis University Veterinary Faculty Animal Hospital. Otherwise bluetongue virus un-vaccinated cattle, goat and sheep blood sera in three province (Samsun, Sivas and Tokat) were added this study. All of the sampled blood sera were tested by commercial c-ELISA kit for investigate the presence of BTV antibody. At the end of the c-ELISA test, bluetongue seropositivity was not detected in dog and bovine sera, but goat and sheep bluetongue seroprevalences were detected 65.2\% (Tokat and Samsun) and 8.6\% (Sivas). As a result, it was suggested that comprehensive studies in the provinces where seropositivity is determined in both sheep and goats, and it is necessary to carry out detailed study among street dogs in these provinces.
\end{abstract}

Bu makale Ondokuz Mayıs Üniversitesi Bilimsel Araştrıma 1904- A-Yüksek Lisans Tez Projeleri kapsaminda, PYO. VET.1904.17.006 kodu ile desteklenmiștir.

\section{GİRİŞ}

Mavidil virusu (BTV) Reoviridae ailesi, Orbivirus cinsinde sınıflandırılan, eklem bacaklılarla bulaşan, evcil ve yabani geviş getirenleri etkileyen ekonomik açıdan önemli bir hastalık etkenidir (29). Enfeksiyondan etkilenen bölgelerdeki duyarlı hayvanlar için toplu aşılamaların gereklilik haline gelmesi, hayvan hareketleri ile ticaretinde önemli kisıtlamaların uygulanmaya başlanması ve hastalık ile artan verim kayıpları virusun neden olduğu ekonomik kayıpların artışının sebebi olarak gösterilmektedir (34). Son y1llarda hızlı yayılma eğiliminde oldu$\breve{g} u$ bildirilen mavidil virusu ile ilgili çalışmalar genellikle sı̆̆ır, koyun ve keçilerde yapılmış olsa da virusun BTV-8 suşunun Kuzey ve Batı Avrupa'da sığırlarda enfeksiyon oluşturduğunun saptanmasından sonra bu suşun Kuzey Avrupa'ya nasıl taşınmış olabileceği konusuna açıklık getirebilmek için ortaya atılan teorilerden biri mavidil enfeksiyonunun Afrika gibi endemik bölgelerden evcil köpeklerle taşınmış olabileceği olasılığıdır (11). Köpeklerde mavidil virus varlığının araştırıldığı bir diğer çalışma Amerika'da multivalan (distemper, adenovirus ve parvovirus) modifiye canlı virus aşısı ile aşılanan bir köpekte polimeraz zincir reaksiyonu (PCR) ile BTV-11 RNA sinın tespit edildiği çalışmadır ve çalışmada saptanan mavidil RNA sının kaynağının aşının hazırlandığı sığır hücresi ya da sığır serumunun olabileceği ileri sürülmüştür (1). Evcil köpeklerde mavidil ile ilgili bir diğer çalışmada ise köpeklerin enfekte et veya et ürünlerini ağız yoluyla almaları sırasında ya da enfekte sivrisineğin 1sırması ile enfekte olabilecekleri belirlenmiştir (2). Fas'ta yapılan serolojik çalışmanın sonuçlarına göre ise c-ELISA ile test edilen 187 köpek kan serum örneğinden 40’1 (\% 21) mavidil seropozitif bulunmuştur. Araştırmacılar seropozitif hayvanların sadece ticari yemlerle beslendiğini, dışardan enfekte 
et almadıklarını dolayısıyla enfeksiyonun enfekte sivrisineğin 1sırması ile oluşmuş olacağını ifade etmişlerdir (22). Deneysel bir mavidil çalışmasında ise koyunlardan izole edilen BTV-1 saha suşu ile köpekleri enfekte eden araştırmacılar inkubasyon süresi sonunda köpeklerden aldıkları kanda viral RNA' y1 saptayabilmişlerdir (23).

Mavidil enfeksiyonlarının epizootiyolojisinde köpeklerin rolünü gündeme getiren bu çalışmalar konu ile ilgili daha fazla çalışmaya ihtiyaç olduğunu da bildirmişlerdir.

Türkiye' de ise mavidil enfeksiyonu ile ilgili Ruminantlarla yapılmış birçok çalışma bulunmakla birlikte $(3,4,8,31,15,16)$ köpeklerde enfeksiyonun varlığının araştırıldığ çalışma bulunmamaktadır. Bu çalışma 'Türkiye' de köpeklerde mavidil virus seroprevalansının araştırıldığı ilk çalışmadır.

\section{GEREÇ ve YÖNTEM}

\section{Kan Örnekleri}

Karadeniz Bölgesi' ndeki 6 ilden (Samsun, Trabzon, Sinop, Ordu, Giresun ve Artvin) Ondokuz Mayıs Üniversitesi (OMÜ) Veteriner Fakültesi Hayvan Hastanesine daha önce distemper ve/ veya parvovirus aşıları ile aşılanmıs köpeklerden kan örnekleri silikonlu tüplere alındı. Ayrıca mavidil aşılaması yapılmadığı bildirilen sı̆̆ır (Tokat), keçi (Tokat ve Samsun) ve koyunlardan (Tokat ve Sivas) toplanan kan serumu örnekleri de çalışmaya dahil edildi. Numunelerin toplandığı iller ve hayvan sayıları Tablo 1 de gösterildi.

\section{Kan serum örneklerinin hazırlanması}

Silikonlu tüplere alınan kan örnekleri pihtılaştıktan sonra 10 dakika 1500 rpm devirde santrifüj edilerek serumları ayrıldı ve stok tüplere aktarılarak test edilinceye kadar $-20{ }^{\circ} \mathrm{C}$ 'de sakland1.

$$
\text { Kompetatif ELISA (c-ELISA) }
$$

Örneklenen köpek, sığır, keçi ve koyunların mavidil enfeksiyonu seroprevalanslarını serotip ayrımı yapmadan belirlemek amac1 ile c-ELISA testi ((ID Screen ${ }^{\circledR}$ Bluetongue Competition ELISA kiti) uygulandi. Test, daha önce bildirdiği yöntemle ve üretici firmanın önerileri doğrultusunda yapıldı (13). Test sonunda pleytler 450 nanomikron (nm) filtrede okunup, üretici firmanın talimatındaki formülle hesaplanarak değerlendirildi.

\section{BULGULAR}

Samsun OMÜ Veteriner Fakültesi Kliniklerinden örneklenen 92 adet köpek kan serumu ve Tokat, Samsun ve Sinop' tan örneklenen 92 adet sığır kan serumunda mavidil virus antikoruna rastlanmadi.

Ancak 'Tokat' dan toplanan 92 adet keçi kan serumunun 60 adedi c-ELISA testi sonunda mavidil enfeksiyonu yönünden seropozitif bulunurken, enfeksiyonun seroprevalansinin $\%$ 65.2 olduğu hesapland1. Ayrica, Tokat, Sivas ve Samsun' dan toplanan 92 adet koyun kan serumundan 8 adedinde de mavidil virus antikoru varlığ saptand1 ve enfeksiyon seroprevalansı \% 8.6 olarak belirlendi (Tablo 2).

\section{TARTIŞMA}

Dünyada c-ELISA ile yapılan sı̆̆ır mavidil virus seroprevalans araştırmalarında, Arnavutluk' ta \%18.9, Kazakistan’ da $\% 25.4$, ABD' de $\% 1.49, \% 0.97$ ve \% 2.18 gibi değişen oranlarda ve Hindistan' da \% 75.49 oranında seropozitiflik bildirmişlerdir $(7,12,20,21)$.

Tablo 1. Numunelerin İllere göre dağılımı

Table 1. Distribution of samples by provinces

\begin{tabular}{|c|c|c|c|c|c|c|c|c|}
\hline \multirow{2}{*}{ 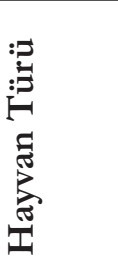 } & \multicolumn{8}{|c|}{-ÖRNEKLEMENİN YAPILDIĞI İL / İLÇELER } \\
\hline & Ordu & Samsun & Giresun & Sivas & Trabzon & Tokat & Sinop & Artvin \\
\hline Keçi & - & 14 & - & - & - & 78 & - & - \\
\hline Köpek & 8 & 71 & 5 & - & 1 & - & 6 & 1 \\
\hline Koyun & - & - & - & 55 & - & 37 & - & - \\
\hline Sı̆̆ır & - & - & - & - & - & 92 & - & - \\
\hline
\end{tabular}

Tablo 2. Mavi Dil enfeksiyonunun türlere göre seroprevalans1

Table 2. Seroprevalence of Blue Tongue infection by species

\begin{tabular}{llll}
\hline Tür & Say1 & Seropozitif Hayvan Sayıs1 & $\mathbf{\%}$ \\
\hline Köpek & 92 & - & - \\
Sığır & 92 & - & - \\
Keçi & 92 & 60 (Tokat ve Samsun) & 65.2 \\
Koyun & 92 & 8 (Sivas) & 8.6 \\
\hline
\end{tabular}


Ülkemizde yapılan sı̆̆ır mavidil çalışmalarında ise, Güney ve Güneydoğu bölgesi ile Ege bölgelerinde \%15.5, Gaziantep'de \%64.52, Batman'da \%75.21, Adiyaman'da \%29.3, Diyarbak1r'da \%63.83, Şanliurfa'da \%66.67, Mardin'de \%51.76, Kilis'de \%27.54, Siirt'de \%43.66 ve Şırnak'da \%22.39 oranında seroprevalans bildirilmiştir (9, 25). Ülkemizin Kuzeydoğu Anadolu Bölgesi’ ndeki sığılarda ise \%48.02, \%15.5 ve Trakya yöresinde \%73.54 oranında seropozitiflik saptanmıştır (18, 31, 32). Karadeniz Bölgesi’ nde daha önce yapılan araştırmalarda ise Rize’ deki sığırlarda \%25 oranında mavidil seropozitifliği bulunmuştur (19). Bu çalışmada ise 'Tokat' dan mavidil aşısı olmayan 92 sığır örneklenmiş ve c-ELISA testi sonunda hiçbirinin mavidil antikoru taşımadıkları belirlenmiştir.

Dünya' da yapılan araştırmalarda keçilerde mavidil seroprevalansının \%1.3 ila \%68.2 oranında değiștiği ifade edilmiştir $(26,33)$. Türkiye'deki ise keçilerde Elazığ’ da \%7.99, Konya'da $\% 16$, Burdur' da $\% 53.5$, Samsun ve çevre ilçelerinde ise $\% 15$, $\% 4$ ve $\% 6.79$ oranında mavidil seroprevalansı bildirilmiştir (6, $8,14,16,24)$. Bu çalışmada ise Tokat ve Samsun'dan örneklenen toplam 92 keçi serumuna yapılan c-ELISA testi sonunda 60 adedi mavidil yönünden seropozitif bulundu ve incelemenin yapıldığ 1 illerdeki enfeksiyonun seroprevalansı \%65.2 olarak hesapland1. Çalışmada keçilerde en yüksek seropozitiflik \%75.64 ile Tokat ilinde belirlendi. Samsun'da ise \%7.14 oranında seropozitiflik saptandı. Daha önce Tokat ili ile ilgili mavidil seropozitifliği bildirilmediğinden sonucun il bazında karşılaştırılması yapılamadı ancak Samsun ve çevre ilçelerinde belirlenen seropozitiflikler ile benzer olduğu görüldü $(16,24)$.

Dünya' da koyunlarda ELISA ile yapılan mavidil seroprevalans çalışmalarında ise Kazakistan’ da \%21.4 ve Hindistan'da \%8.25 oranında pozitiflik tespit etdilmiştir $(20,26)$. Türkiye'de koyunlarda mavidil enfeksiyonuyla ilgili yapılan çalışmalarda ise seropozitiflik oranlarının \%0-\%46 arasında saptanmıştır (6, $8,9,10,17,30)$. Bu çalışmada ise Tokat ve Sivas' dan örneklenen 92 koyun kan serumuna uygulanan c-ELISA testi sonunda Sivas' da 8 (\%8.6) koyunun mavidil seropozitif olduğu tespit edildi ve oranın Türkiye' de daha önce bildirilen oranlarla benzer olduğu görüldü.

Dünyada köpeklerde mavidil enfeksiyonu varlığı araştırmalar1 1994 yılında başlamış ve aralıklarla devam etmiştir. Amerika' da multivalan (distemper, adenovirus ve parvovirus) modifiye canlı virus aşısı ile aşılanan bir köpekte ve Afrika yaban köpeğinde virusun varlığı bildirilmiştir $(1,2)$. Köpeklerde c-ELISA ile yapılan serolojik çalışmalarda ise Fas'ta \%21 oranında ve Amerika' da \%40 oranında mavidil seropozitifliği bildirmişlerdir $(13,22)$. Ayrıca Amerika' da yapılan çalışmada araştırmacılar agar jel immunodifüzyon (AGID) testi ile yaptıkları taramada ise c-ELISA ile pozitif bulunan 8 örneğin 3'ünü tespit edebilmişler ve çalışma sonunda c-ELISA'nın köpeklerde mavidil taraması için daha etkili bir test olduğunu ve zayıf pozitiflikleri de tespit edebildiğini ileri sürmüşlerdir (13). Bu çalışmada ise Samsun ve çevre illerdeki köpeklerden alınan 92 kan serumunun tamamı mavidil c-ELISA testi ile tarand1 ve test sonunda serumlarda seropozitifliğe rastlanılmadı. Köpeklerde pozitifliğe rastlanmaması örnekleme yapılan aşılı hayvanlarda aşı kaynaklı bir bulaş olmadığını düşündürdü. Seropozitiflik bildirilen illerden (Tokat ve Sivas) Hayvan Hastanesine hiç köpek gelmediği için örnekleme yapılamadı ve bu illerdeki köpeklerde mavidil seroprevalansı belirlenemedi.

\section{SONUÇ}

Sonuç olarak incelenen illerden Tokat ve Samsun' da keçilerde, Sivas' da ise koyunlarda pozitifliklerin bulunduğu, bu nedenle de özellikle en yüksek seropozitifliğe sahip olan Tokat ve Sivas illerinin çevresinde konu ile ilgili gerekli tedbirlerin alınabilmesini sağlamak için daha geniş örneklemelerin yapılarak bölgenin taranması ülke hayvancılığı açısından önemlidir.

Yakın zamanda dünya da köpeklerde varlığ1 serolojik ve virolojik olarak bildirilen ve deneysel çalışmalarda viral nükleik asitin saptandığ1 araştırmalar ile mavidil virusunun epidemiyolojisinde köpeklerin rolü gündeme gelmeye başlamıştır. Mavidil ile enfekte et veya et ürünlerinin ağ1z yoluyla alımı, enfekte sivrisineğin ısırması ve aşılamaların gerekçe gösterildiği çalışmalarda köpeklerin mavidil ile enfekte olabilecekleri belirlenmiştir. Bu çalışma ile Türkiye'de köpekle de mavidil enfeksiyon seroprevalansı ilk kez araştırılmış ve köpek kan serumlarının örneklendiği illerde mavidil seropozitifliği saptanamamıştır. Ancak çalışmamızda seropozitifliğin saptandığı iller olan 'Tokat, Sivas ve Samsun' da özellikle sokak köpeklerinde taramaların arttırılması ve konu ile ilgili daha fazla bilgi sahibi olunmasının gerekli olduğu düşünülmüştür. Mavidil enfeksiyonu mücadelesinde kontrollü hayvan hareketleri, enfekte hayvanların imhası ve hayvanların vektörle temasinın önlenmesi ya da vektör kontrolü enfeksiyon riskini azaltılabilir. Ayrıca yapılacak seroprevalans çalışmaları ile enfekte bölgelerin belirlenmesi ve buralarda vektör mücadelelerinin arttırllmas1, sıv1 birikimi olan alanlarda tedbirlerin alınması ile vektöre karş1 insektisit kullanımı önemlidir (5, 27, 28). Bu koruma ve kontrol faaliyetlerinin yanısıra mavidil enfeksiyonunun epidemiyolojisinde köpeklerin rolü ile ilgili daha kapsaml çalışmaların planlanmasının bu hastalıkla mücadelede yeni çözüm yolları sunabileceği düşünülmektedir.

\section{BEYANNAMELER}

\section{Etik Onayı}

Bu çalışma Ondokuz Mayıs Üniversitesi Hayvan Deneyleri Yerek Etik Kurulunun 26.10.2016 tarihli toplantısında 2016-27/50 karar sayısı ile etik onayı almıştır.

\section{Çıkar Çatışması}

Yazarlar arasında herhangi bir çıkar çatışması yoktur.

\section{Yazar Katk1ları}

Fikir, Kavram ve Tasarım: S.G

Veri Toplama ve Analiz: E.B

Makalenin Yazımı: S.G., E.B.

Eleştirel İnceleme: S.G.

\section{Veri kullanılabilirliği}

Bu çalışmanın verileri yazarlara aittir.

\section{Teşekkür}

Bu makale Ondokuz Mayıs Üniversitesi Bilimsel Araştrıma 1904A-Yüksek Lisans Tez Projeleri kapsaminda, PYO.VET.1904.17.006 kodu ile desteklenmiştir. 


\section{KAYNAKLAR}

1. Akita GY, Ianconescu M, MacLachlan NJ, Osburn. BI, Greene RT, et al. Bluetongue disease in dogs associated with contaminated vaccine. Vet Rec. 1994;134:283-284.

2. Alexander KA, MacLachlan NJ, Kat PW, House C, O)Brien SJ, Lerche NW, et al.. Evidence of natural bluetongue virus infection among African carnivores. Am J Trop Med Hyg. 1994;51:568-576.

3. Albayrak H, Özan E. Seroprevalence of some arboviral infections transmitted by blood sucking insects in ruminants and equids in the middle Black Sea region in Turkey. Kafkas Univ Vet Fak Derg. 2010;16:33-36.

4. Azkur AK, Gazyagc1 S, Aslan ME. Serological and Epidemiological Investigation of Bluetongue, Maedi-Visna and Caprine Arthritis-Encephalitis Viruses in Small Ruminant in Kirikkale District in Turkey. Kafkas Univ Vet Fak Derg. 2011;17:803-808.

5. Breard E, Hamblin C, Hammounı S, Sa1leau C, Dauphin G, Zientara S. The epidemiology and diagnosis of bluetongue with particular reference to corsica. Res In Vet Sci. 2004;77:18.

6. Bolat Y. Investigation of antibodies of the bluetongue diseases in sera of cattle and goats in Elazığ. Doğa Tr J Vet Sci,1986;10(3):2035-238.

7. Boyer TC, Ward MP, Wallace RL, Singer RS.Regional seroprevalence of bluetongue virus in cattle in Illinois and western Indiana. Am J Vet Res 2007;68(11):1212-9.

8. Bulut O, Yavru S, Yapkıç O, Şimşek A, Kale M, Avci O. Serological investigation of bluetongue virus infection by serum neutralization test and elisa in sheep and goats. Bull Vet Inst Pulawy. 2006;50:305-307.

9. Burgu I, Urman HK, Akca Y, Yonguc A, Mellor PS, Hambling C. Serologic survey and vector surveillance for bluetongue in southern Turkey. In, "Bluetongue, African Horse Sickness and Related Orbivirusus: Proceeding of the Second International Symposium". Eds, TE Walton, BI Osburn, 1992;168-174.

10. Burgu İ, Öztürk F, Akça Y. Tahirova devlet üretme çiftliği koyunlarında viral enfeksiyonlar üzerine serolojik araştırmalar. A Ü Vet Fak Derg. 1984;31:167-179.

11. Darpel KW, Batten CA, Veronesi E, et al. Clinical signs and pathology shown by British sheep and cattle infected with bluetongue virus serotype 8 derived from the 2006 outbreak in northern Europe. Vet Rec. 2007;161:253-261.

12. Di Ventura M, Tittarelli M, Semproni G, Bonfini B, Savini G, Conte A and Lika A. Serological Surveillance Of Bluetongue Virus In Cattle, Sheep And Goats In Albania. Vet Ital. 2004;40,3,101-104.

13. Dubovi, E.J, Hawkins M., Robert A, Griffin Jr., Johnson D.J., Ostlund E.N. Isolation Of Bluetongue Virus From Canine Abortions. Journal of Veterinary Diagnostic Investigation
2013, 25(4):490-492.

14. Ertürk A. Çeşitli serumlarda (koyun, keçi, sığır) mavi dil antikorlarının agar- jel presipitasyon testi ile araştırılması. Etlik Vet Mikrob Derg. 1994;7:1-19.

15. Gumusova Okur S, Yazici Z, Albayrak H. Serological investigation of Bluetongue virus in sheep in the middle Black Sea Region. Vet Hek Mikrob Dern Derg, 2006;6:9-11.

16. Gumusova-Okur S, Memis YS. Caprine Arthritis Encephalitis and Bluetongue Virus Infections in Maltese, Saanen and Hair Goat Breeds. PJZ. 2016;48,5:1567-1569.

17. Gür S. A serological investigation of bluetongue virus (BTV) in cattle, sheep and gazella subgutturosa subgutturosa in southeastern Turkey. Trop. Anim. Health Prod. 2008;40,3:21721.

18. Karaoğlu T., Özgünlük İ., Demir B., Özkul A., Burgu I., 2007. Seroprevalence of culicoidesborne disease in cattle in European Turkey. Ankara Üniversitesi Veteriner Fakültesi Dergisi, 54, 121-125.

19. Kulaç E, Kırmızıgül AH, Yıldırım Y Rize Yöresindeki Suğırlarda Mavi Dil Enfeksiyonunun Seroprevalans1. Atatürk Üniversitesi Vet. Bil. Derg. 2016;11(2):151-158.

20. Lundervold M, Milner-Gulland EJ, O'Callaghan CJ, Hamblin C, Corteyn, A, Macmillan AP. A serological survey of ruminant livestock in Kazakhstan during post-Soviet transitions in farming and disease control. Acta Vet Scand. 2004;45:211-224.

21. Maan S, Tiwari A, Chaudhary D, Dalal A, Bansal N, Kumar V, et al. Comprehensive Study on Seroprevalence of Bluetongue Virus in Haryana State of India. Vet World 2017;10(12):1464-1470.

22. Oura CAL, El Harrak M. Midge-transmitted bluetongue in domestic dogs. Epidemiol Infect. 2011;139:1396-1400.

23. Oura CAL, Sebbar G, Loutfi C, et al. No evidence for replication of a field strain of bluetongue virus serotype 1 in the blood of domestic dogs, Research in Veterinary Science. 2014;96,1:217-219.

24. Ozan E, Turan HM, Albayrak H, Cavunt A. Serological determination of pestivirus, bluetongue virus and peste des petits ruminants virus in small ruminants in Samsun province of Turkey Atatürk Üniv Vet Bil Derg. 2012;1:27-33.

25. Özgünlük İ. Güneydoğu Anadolu Projesi (GAP) kapsamındaki bölgede sığırlarda mavidil, akabane ve ibaraki enfeksiyonlarının seroepidemiyolojisi. Doktora Tezi, Ankara Üniversitesi Sağlık Bilimleri Enstitüsü, Ankara. 2003.

26. Ravishankar C, Krishnan-Nair G, Mini M, Jayaprakasan V. Seroprevalence of bluetongue virus antibodies in sheep and goats in Kerala state, India. Rev Sci Tech Off int Epiz. 2005;24(3):953-958.

27. Saltık HS, Kale M. Mavidil Virus Hastalı̆̆ı. MAKÜ Sag. Bil. Enst. Derg. 2017; 5(1): 32-44. 
28. Savini G, MacLachlan J, Sanchez-Vizcaino JM, Zientara S. Vaccines against bluetongue in Europe. Microbiol Infect Dis. 2008;31(2-3):101-20.

29. Verwoerd D, Erasmus BJ. In: Infectious Diseases of Livestock. 2. Coetzer JAW, Tustin RC, editors. Oxford University Press, Cape Town, South Africa. 2004;1201-1230.

30. Yavru S, Öztürk F, Gürhan İ, Şimşek A, Ünver G, Duman R, Yapkıç O. Koyunlarda Solunum Yolu Viruslarının Serolojik Olarak Araştır1lması. Hayv Araş Derg. 1999;9(1-2):53-60.

31. Yıldırım Y, Burgu İ, Kuzeydoğu Anadolu bölgesindeki sığırlarda mavidil (BT), IBR, PI-3, EBL ve BVD enfeksiyonlarının seroprevalans1, Ankara Üniv Vet Fak Derg. 2005;52:113-117.

32. Yildirım Y, Yilmaz V. Seroprevalence of bluetongue virus 4, 9 and 16 serotypes in cattle in various North-eastern provinces of Turkey. Revue Med Vet. 2010;161:8-9,372-375.

33. Yousef MR, Al-Eesa AA, Al-Blowi MH. High seroprevalence of bluetongue virus antibodies in Sheep, Goats, Cattle and Camel in different districts of Saudi Arabia J Vet World. 2012;5(7):389-393.

34. Zientara S, MacLachlan NJ, Calistri P, Sanchez-Vizcaino JM, Savini G. Bluetongue vaccination in Europe. Expert Rev Vaccines. 2010;9:989-991. 